Int. J. Dev. Biol. 55: 261-268 (2011)

doi: $10.1387 / \mathrm{ijdb} .103167 \mathrm{dr}$

\title{
The role of pericytes in angiogenesis
}

\author{
DOMENICO RIBATTI*,1, BEATRICE NICO ${ }^{1}$ and ENRICO CRIVELLATO ${ }^{2}$
}

\begin{abstract}
${ }^{1}$ Department of Human Anatomy and Histology, University of Bari Medical School, Bari, and ${ }^{2}$ Department of Medical and Morphological Research, Anatomy Section, University of Udine Medical School, Udine, Italy
\end{abstract}

\begin{abstract}
Pericytes are branched cells embedded within the basement membrane of capillaries and post-capillary venules. They provide an incomplete investment to endothelial cells, thus reinforcing vascular structure and regulating microvascular blood flow. Pericytes exert an important role on endothelial cell proliferation, migration and stabilization. Endothelial cells, in turn, stimulate expansion and activation of the pericyte precursor cell population. The balance between the number of endothelial cells and pericytes is highly controlled by a series of signaling pathway mechanisms operating in an autocrine and/or paracrine manner. In this review, we will first examine the molecular aspects of the pericyte activating factors secreted by endothelial cells, such as platelet derived growth factor B (PDGF-B), vascular endothelial growth factor (VEGF), transforming growth factor beta (TGF- $\beta$ ) and angiopoietins (Angs), as well as signaling pathways involving Notch and ephrins. We will then consider the complex and multivarious contribution of pericytes to the different aspects of angiogenesis with particular emphasis on the potential role of these cells as targets in tumor therapy.
\end{abstract}

KEY WORDS: angiogenesis, antiangiogenesis, pericyte, tumor growth

\section{Historical background}

Pericytes are advential cells located within the basement membrane of capillary and post-capillary venules. Because of their multiple cytoplasmic processes, distinctive cytoskeletal elements and envelopment of endothelial cells, pericytes are generally considered to be cells that stabilize the vessel wall, controlling endothelial cell proliferation and thereby the growth of new capillaries. In addition, they are believed to participate in the regulation of microvascular blood flow via a contractile mechanism.

Charles Rouget was the first to describe branched, nonpigmented cells on the capillary wall of the hyaloid of the frog and regarded them as contractile elements (Rouget, 1873, 1874, 1879), but he was unable to stain these cells and concluded that they were muscle cells. Staining of Rouget cells was successfully carried out by Mayer in 1902, using methylene blue. Mayer (1902) suggested that pericytes merge into smooth muscle cells of the tunica media or arteries.

Vimtrup (1922), studying capillaries in tails of different young living larvae, noted that "the contraction of capillaries begins at one of these cells (pericytes), spreading in both directions, at first slowly, later significantly faster". He confined his studies to areas where the afferent arterioles and the efferent venules were clearly visible, thus allowing unequivocal identification of the capillary segment in-between. He termed the observed contractile population as "Rouget cells".

The term pericytes was later coined by Zimmermann in 1923. He demonstrated that pericytes were: a) present around capillaries in a wide range of species including fish, amphibians, reptiles, birds and mammals; b) continuous with smooth muscle cells of arteries and veins; c) highly branched with distinctive cytoplasmic processes within each capillary bed. Moreover, Zimmermann held that contraction of these cells controlled capillary permeability and distinguished three subgroups of pericytes, depending on the type of vessel pericytes are located at, but already considered the existence of a continuum with countless forms of differentiation.

\section{Pericyte markers}

Pericytes are commonly identified by molecular markers, such as alpha smooth muscle actin, non-muscle myosin, tropomyosin,

\footnotetext{
Abbreviations used in this paper: Ang, angiopoietin; Eph, ephrin; NG, nerve/ glial antigen; PDGF, platelet-derived growth factor; TGF, transforming growth factor; VEGF, vascular endothelial growth factor.
}

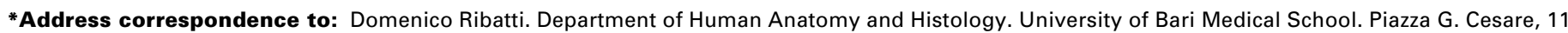
Policlinico, E-70124 Bari, Italy. Fax: +39.080.5478310. e-mail: ribatti@anatomia.uniba.it
} 
desmin, nestin, platelet derived growth factor receptor- $\beta$ (PDGFR$\beta$ ), aminopeptidase $A$, aminopeptidase $N(C D 13)$, sulfatide or nerve/glial antigen-2 (NG2) proteoglycan (Morikawa et al., 2002) (Fig. 1). Pericytes on normal capillaries typically express desmin, but not alpha smooth muscle actin, whereas smooth muscle cells on arterioles and pericytes on venules are immunoreactive for both (Nehls and Drenckhahn, 1993; Morikawa et al., 2002). Other reports have suggested that alpha smooth muscle actin may be considered a general marker for pericytes (Hellstrom et al., 1999; Ohlsoon et al., 1999).

\section{The balance between endothelial cells and pericytes}

The balance between the number of endothelial cells and pericytes seems to be highly controlled. Potential regulators include soluble factors acting in an autocrine and/or paracrine manner, mechanical forces secondary to blood flow and blood pressure, as well as homotypic and heterotypic cell contacts.

Severals molecules are involved in the control and modulation of the interactions occurring between pericytes and endothelial cell, such as PDGF-B, transforming growth factor beta (TGF- $\beta$ ), vascular endothelial growth factor (VEGF), angiopoietins (Angs), signaling pathways involving Notch and ephrins (Hughes, 2008; von Tell et al., 2006).

\section{Endothelial production of PDGF-B is required for peri- cyte recruitment}

Endothelial cells secrete PDGF-B and pericytes express PDGFR- $\beta$ (Betsholtz, 2004), suggesting a paracrine mode of interaction between these two cell types (Fig. 2). PDGF-B promotes pericyte precursor cell proliferation and migration and mice deficient for PDGF-B or PDGFR- $\beta$ die during embryonic development with widespread microvascular defects, consisting in vessel dilatation and microaneurysms. In most tissues of these animals pericyte association with vessels is drastically reduced (Betsholtz,

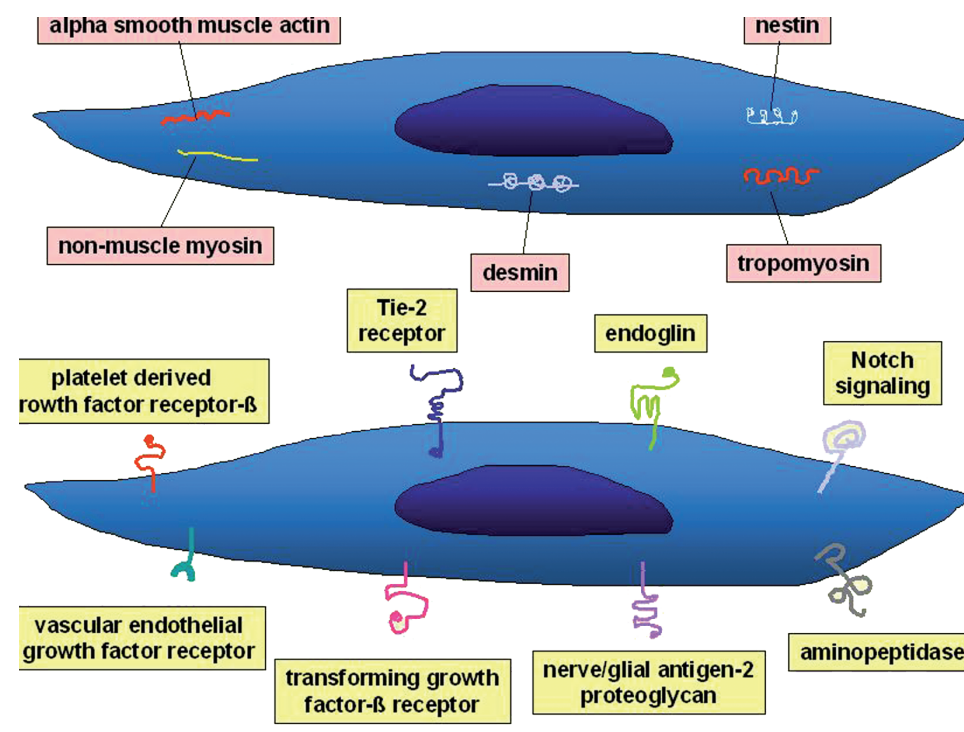

Fig. 1. Cytoplasmic markers (above) and membrane determinants (below) expressed by pericytes.
2004). Endothelial cells of the sprouting capillaries in the PDGF$B$ deficient mice were unable to attract PDGFRB- $\beta$-positive progenitors of pericytes. Failure to recruit pericytes during development leads to vascular instability and regression (Benjamin et al., 1998; Leveen et al., 1994; Lindbloom et al., 2003).

Greenberg et al. (2008) demonstrated that under conditions of PDGF-mediated angiogenesis, VEGF abolished pericyte coverage of vascular sprouts, leading to vessel destabilization. VEGFmediated activation of VEGFR-2 suppressed PDGFR- $\beta$ signaling, through the induction of a VEGFR-2/ PDGFR- $\beta$ complex (Fig. 2).

\section{TGF- $\beta 1$ contributes to the differentiation of precursor cells into pericytes}

When mesenchymal cells are co-cultured with endothelial cells or treated with TGF- $\beta 1$, they express smooth muscle cell markers, indicating differentiation of precursor cells into pericytes or smooth muscle cells (Darland and D'Amore, 2001). Mice deficient for endoglin, a TGF- $\beta 1$ co-receptor, display reduced association with smooth muscle cells and pericytes (Li et al., 1999). TGF- $\beta 1$ inhibits endothelial cell proliferation and migration, and mice deficient for TGF- $\beta 1$ signaling components show dilated and irregularly shaped microvessels (Lebrin et al., 2005). Overall, these data indicate that TGF- $\beta 1$ appears to be instrumental for the de novo induction of pericytes by regulating differentiation of pericyte progenitors.

\section{VEGF induces proliferation and migration of pericytes and pericyte-derived VEGF promotes endothelial cell survival}

VEGF directly induces proliferation and migration of pericytes in hypoxic conditions (Yamagishi et al., 1999) and also indirectly stimulate pericyte recruitment via endothelial cell production of nitric oxide (NO). In turn, NO promotes mural precursor cell migration in vitro and pericyte recruitment to tumor vessels in vivo (Kashiwagi et al., 2005). Treatment with VEGF inhibitors causes pericytes to become closely associated with surviving tumor vessels in Lewis lung carcinomas, RIP-Tag2 tumors (Inai et al., 2004) and other tumor models (Tong et al., 2004; Willett et al., 2004).

Darland et al. (2003) demonstrated that pericytes cocultured with endothelial cells produce VEGF that may act in a juxtacrine/paracrine manner as a survival and/or stabilizing factor for endothelial cells. Moreover, they observed VEGF gene expression in developing retinal vasculature in pericytes contacting newly formed microvessels.

\section{Pericyte-derived Ang-1 promotes endothelial cell survival and Ang-2 acts as a destabilizing factor and the balance of Ang-1 and Ang-2 signaling regulates pericyte recruitment}

The Angs family consists of Ang-1, -2 , and the orthologous Ang-3 in mouse and Ang-4 in human. All Angs bind the endothelial-specific receptor tyrosine kinase Tie-2 (also known as TEK) and play a critical role in endothelial sprouting, vessel wall remodeling and mural cell recruitment (Thurston, 2003). 


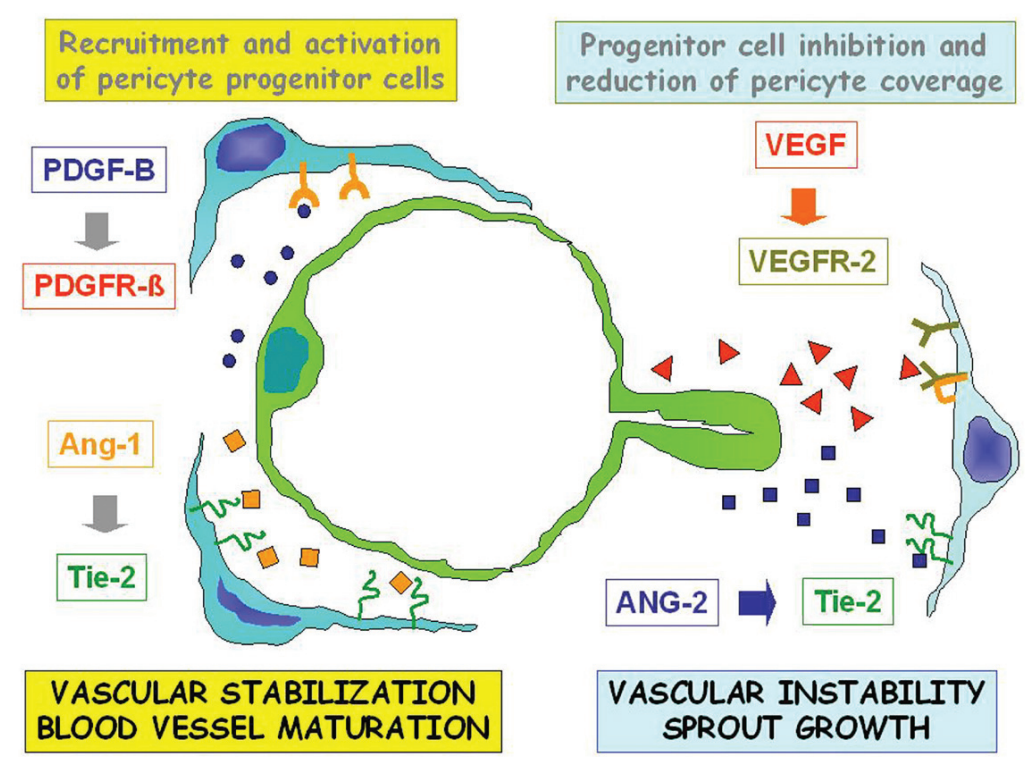

Fig. 2. Schematic drawing that illustrates the paracrine interactions occurring between pericyte precursor cells and endothelial cells in PDGF-mediated angiogenesis. Endothelial cells secrete PDGF-B, that causes pericyte precursor cell proliferation and migration through activation of PDGFR- $\beta$ receptors. Pericytes surround and cover early endothelial tubes. By contrast, endothelial cells in vascular sprouts release VEGF, which in turn mediates suppression of PDGFR$\beta$ signaling through the induction of VEGFR-2/PDGFR- $\beta$ complexes. This pathway abrogates pericyte coverage of endothelial sprouts leading to vascular instability and regression.

Ang- 1 is produced by pericytes and smooth muscle cells, activates endothelial Tie-2, maximizes interactions between endothelial cells and pericytes and is expressed behind the leading edge of angiogenic vessels, a position consistent with vessel maturation (Sundberg et al., 2002). Mice deficient for either Ang1 or Tie-2 die during embryonic development with vascular defects similar to those observed for PDGF-B deficient mice (Jones et al., 2001). Ultrastructural analysis suggests that Tie-2knock out blood vessels lack mural cells (Patan, 1998). In PDGF$B$ deficient mice, recombinant Ang-1 restored the vascular structure and permeability in the growing retinal vasculature (Uemura et al., 2002). Moreover, Ang-1 also counteracts VEGF-induced endothelial leakiness (Thurston et al., 1999).

Ang-2 is expressed by endothelial cells located at the leading edge of proliferating vessels (Maisonpierre et al., 1997) and acts as a destabilizing factor which is restricted to endothelial cells in areas of vascular remodeling and binds Tie-2 without inducing signal transduction (Maisonpierre et al., 1997).

Expression of both Ang-2 and Tie-2 in pericytes has been also reported (Wakui et al., 2006; Cai et al., 2008). VEGF increases production of Ang-2, and overexpression of Ang-2, which binds to Tie-2 in competition with Ang-1, by endothelial cells results in dissociation of pericytes from vessels (Zhang et al., 2003), reduces pericyte coverage and destabilizes vessels within the tumor even in the presence of VEGF stimulation (Cao et al., 2007). Moreover, transgenic mice overexpressing Ang-2 in the retina develop dense vascular networks with reduced pericyte coverage (Feng et al., 2007). De Palma et al. (2005) demonstrated that monocytes expressing Tie-2 (TEMs) are a distinct haemopoietic lineage of proangiogenic cells and distinguished a subpopulation of tumor stroma-derived mesenchymal progenitor cells representing a primary source of tumor pericytes.

\section{NG2 and Notch-3 mediate pericyte-endothelial interactions}

Immature pericytes express the NG2 proteoglycan during early stages of angiogenesis and soluble NG2 promotes endothelial cell motility and angiogenesis forming a complex with galectin-3 and $\alpha 3 \beta 1$ integrin on the cell surface (Fukushi et al., 2004). Both blocking by antibodies as well as knocking out of the gene encoding NG2 abrogated vascular growth (Ozerdem and Stallcup, 2004). Virgintino et al. (2007) have shown that microvessels of the fetal human telencephalon are characterized by a continuous layer of NG2-positive pericytes, which tightly invest endothelial cells in the earliest stages of vessel growth.

Notch signaling is a highly conserved pathway, initially discovered in Drosophila development (Baron et al., 2002). There are four Notch receptors (Notch 1-4) and five ligands (Jagged-1, and-2, Delta 1, -3, -4) (Iso et al., 2003). All the receptors and ligands are expressed in at least one vascular compartment, e.g. arteries, veins, capillaries, muscle cells or pericytes.

Notch signaling is required for remodeling the primary vascular plexus into the hierarchy of mature vascular beds and maintaining arterial fate (Alva and Iruela-Arispe, 2004). The Notch-3 receptor is highly expressed in pericytes and disruption of Notch-3 signaling in Notch-3 -/- mutant mice results in enlarged vessels due to the lack of pericytes (Wang et al., 2007). Patients suffering from CADASIL (Cerebral Autosomal Dominant Arteriopathy with Subcortical Infarcts and Leukoencephalopathy) syndrome, pathology associated with mutations of Notch-3, present vessels lacking pericytes (Louvi et al., 2006). In dental pulp, perivascular cells mainly express Notch-3 (Lovschall et al., 2007) and in the retina pericytes express also Notch-3 (Claxton and Fruttiger, 2004). More recently, Liu et al. (2009) showed that knockdown by small interfering RNA revealed that Notch-3 signaling is necessary for endothelial-dependent mural cell differentiation, and Notch-3 contributes to the pro-angiogenic capability of mural cells co-cultured with endothelial cells.

\section{Ephrins and Eph receptors}

The discovery that members of the ephrins (Eph) family are differentially expressed in arteries and veins from very early stages of development has been one of the first indications that artery-vein identity is intrinsically programmed. Eph-B2 is expressed in arterial endothelial cells. The principal receptor for Eph-B2, Eph-B4, displays a reciprocal expression pattern in embryonic veins (Bratley-Siders and Chen, 2004). Mutations of the Eph-B2 and of Eph-B4 both lead to early embryonic lethality (Wang et al., 1998; Adams et al., 1999; Gerety et al., 1999; 2002). Remodeling of the primary vascular plexus into arteries and veins was arrested in both mutants, suggesting important roles for EphB2/Eph-B4 interactions on arterial and venous endothelial cells, 
respectively.

Ephrin-B2 is a critical regulator of mural cell migration, spreading and adhesion during vessel wall assembly (Foo et al., 2006). More recently, Salvucci et al. (2009) reported that Eph-B is a critical mediator of postnatal pericyte to endothelial cell assembly into vascular tubes. Furthermore, inhibition of Eph-B activity prevents assembly of pericytes and endothelial cells.

\section{The role of pericytes in angiogenesis}

During the initial phase of angiogenesis, activated pericytes in parent vessels bulge, shorten their processes and increase their volume, an intense cell proliferation occurs, pericytes project into the perivascular spaces, their basement membrane is disrupted and fragmented and appear detached from the vessel wall (DiazFlores et al., 1992). Although initially endothelial cell sprouts may form without pericyte involvement, pericytes are among the first cells to invade newly vascularized tissues and locate at the growing front of the endothelial sprouts by determining the location of sprout formation and by guiding newly formed vessels (Nehls et al., 1992). Individual pericytes can be found at the tips of angiogenic sprouts in the corpus luteum, where pericytes are the first vascular cells to invade the granulose fold of the ruptured follicle, and in tumors (Amselgruber et al., 1999; Gerhardt and Betsholtz, 2003; Morikawa et al., 2002).

It has long believed that endothelial tube formation is followed by investment of pericytes, which use endothelial cell sprouts as migration clues. Accordingly, pericytes are recruited by differentiation from surrounding mesenchymal precursors or by migration from the mural wall of the adjacent vessel (Gerhardt and Betsholtz, 2003). In this way, pericytes suppress endothelial growth (Orlidge and D'Amore, 1987) and migration (Sato and Rifkin, 1989). There is a striking coincidence of pericyte investment and microvessel stabilization (von Tell et al., 2006; Bergers and Song 2005) and pericyte investment has also been directly implicated in conferring capillary resistance to regression in vivo (Benjamin et al., 1998). Clinical evidence for a stabilizing function of pericyte was offered by the finding that the development of microaneurysms of retinal capillaries, as a symptom of diabetic retinopathy, was correlated with an initial loss of intramural pericytes (Kuwabara and Cogan, 1963).

In 1990, Blood and Zetter wrote that: "Formation of a basement membrane and investment of capillaries with pericytes are generally associated with the end of the proliferative stage and the beginning of the mature or quiescent stage of capillary function". More recently, Stratman et al. (2009) have demonstrated that endothelial cell-pericyte interactions regulate increased expression of basement membrane protein genes and proteins, such as fibronectin and laminin, as well as integrins that recognize the remodeled matrices to control this process and these changes occur specifically in endothelial cellpericyte co-cultures and not in endothelial cell only cultures.

Alternatively, pericytes can invade tissues in the absence of endothelial cells and can form tubes enabling the subsequent penetration of endothelial cells (Ozerdem and Stallcup, 2003). Rajantie et al. (2004) showed that bone marrow-derived hematopoietic progenitors cells $\mathrm{CD} 11 \mathrm{~b}^{+}$and CD45 ${ }^{+}$expressing the pericyte marker NG2 were located in close proximity to blood vessels in a subcutaneous B16-F10 melanoma model. Bone marrow-derived PDGFR- $\beta^{+} /$Sca- $1^{+}$progenitor pericytes have been demonstrated in mouse model of pancreatic islet tumorigenesis, which were able to differentiate into mature pericytes expressing the markers NG2 and alpha smooth actin (Song et al., 2005). Virgintino et al. (2007) demonstrated in the human fetal telencephalon that growing microvessels are formed by a pericyte-driven angiogenic process in which endothelial cells are preceded and guided by migrating pericytes.

Overall, these data suggest the existence of a mutual interplay between endothelial cells and pericytes in the direction of the angiogenic process, assigning to the pericytes a putative morphogenetic role.

\section{Pericytes as targets in tumor therapy}

In pathological conditions in which angiogenic activity is enhanced, such as tumors, pericytes are located near blood vessels at the growing front of tumors, where angiogenesis is most active and show morphological abnormalities (Schlingemann et al., 1990; Wesseling et al., 1995; Morikawa et al., 2002). Moreover,

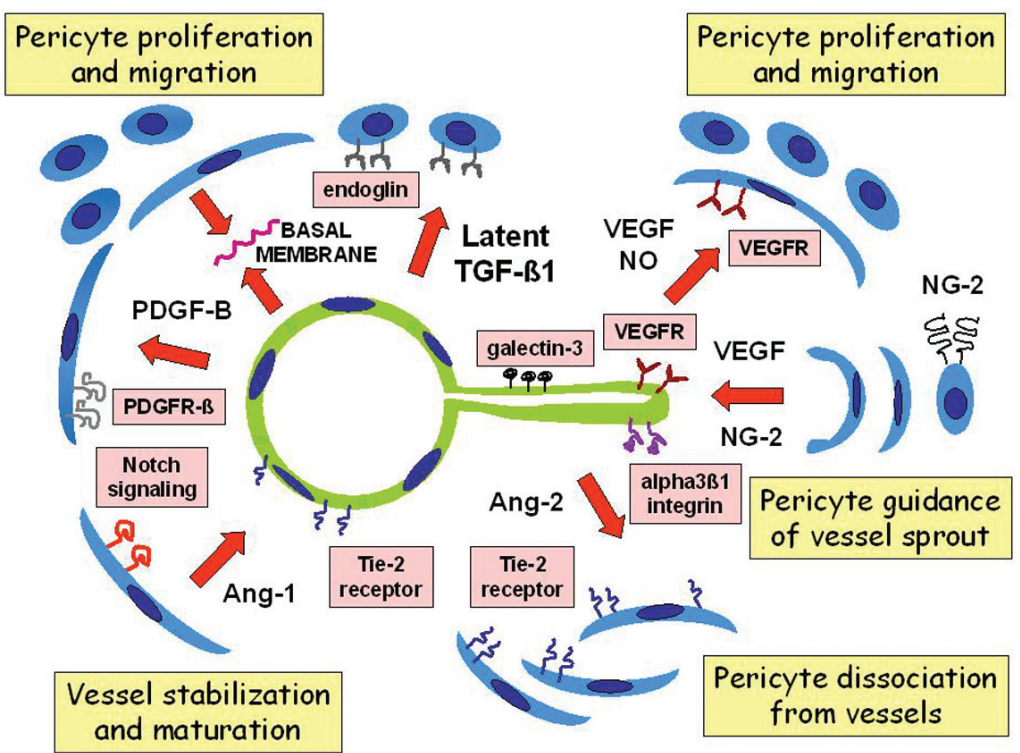

Fig. 3. Signaling pathways operating in endothelial cell/pericyte paracrine cross-talk. Pericytes are involved in endothelial cell stimulation and guidance as well as endothelial stabilization and maturation. Vessel sprouts (right) cause destabilization of pericyte investment through Ang-2/Tie-2 signaling. Pericytes provide guidance for endothelial movement and tube formation through secretion of VEGF and soluble NG-2. Spreading endothelial cells, in turn, stimulate pericyte precursor cell proliferation and migration by releasing VEGF and NO. Vessel stabilization (left) occurs by pericyte investment and close interaction with endothelial cells. Mature endothelial cells secrete PDGF-B, which promotes proliferation and migration of pericyte precursor cells through activation of PDGFR- $\beta$ receptors expressed on the surface of pericyte progenitors. This mechanism leads to pericyte coverage of early endothelial tubes. Vessel maturation further develops through Ang-1-and Notch-mediated signaling. Pericyte stabilize and reinforce the endothelial tube contributing to secretion of basal membrane. 
pericyte deficiency could be partly responsible for vessel abnormalities in tumor blood vessels (Gerhardt and Semb, 2008) and partial dissociation of pericytes (Hobbs et al., 1998; Hashizume et al., 2000) contribute to increased tumor vascular permeability.

VEGF inhibition eliminates tumor vessels without removing pericytes (Morikawa et al., 2002). Antiangiogenic treatment directed against endothelial cells using VEGF inhibitors induces the regression of tumor vessels and decreases tumor size (Baluk et al., 2005), leading to vessel normalization, characterized by increased pericyte coverage, tumor perfusion and chemotherapeutic sensitivity (Jain, 2005). Moreover, removal of VEGF inhibition causes tumor re-growth due to the fact that pericytes provide a scaffold for the rapidly re-growing of tumor vessels (Mancuso et al., 2006).

Pericytes have been indicated as putative targets in the pharmacological therapy of tumors by using the synergistic effect of anti-endothelial and anti-pericytic molecules. Removal of pericyte coverage leads to exposed tumor vessels, which may explain the enhanced effect of combining inhibitors that target both tumor vessels and pericytes. Bergers et al. (2003) showed that combined treatment or pre-treatment with anti-PDGF-B/PDGFBR- $\beta$ reducing pericyte coverage increases the success of anti-VEGF treatment in the mouse RIP1-TAG2 model.

However, extensive regression of endothelial cells was not observed in tumors after inhibition of PDGFR- $\beta$ signaling (Abramsson et al., 2003). STI571 (Gleevec, Imatinib), which targets PDGFRs and other receptor tyrosine kinases, did not reduce vascular density when given alone but did augment the effects of VEGF inhibitors (Bergers et al., 2003). After treatment of RIP1-TAG-2 tumors and Lewis lung carcinomas with AG013737 or VEGF-Trap, surviving pericytes may become more tightly associated with endothelial cells or have no apparent association with tumor vessels (Inai et al., 2004). Treatment of RIP1-TAG2 tumors with anti-PDGFR- $\beta$ antibody for three weeks reduces pericytes, increases endothelial cell apoptosis but does not seem to reduce tumor vascular density (Song et al., 2005). Similarly, the receptor tyrosine kinase inhibitor SU6668, which also affects PDGFR- $\beta$ signaling, detaches and reduces pericytes in RIP1-TAG2 and xenotransplanted tumors, thereby restricting tumor growth (Reinmuth et al., 2001; Shaheen et al., 2001).

Sennino et al. (2007) demonstrated that treatment with a novel selective PDGF-B blockade DNA aptamer AX102 that blocks the action of PDGF-B led to progressive reduction of pericytes in Lewis lung carcinomas. More recently, Murphy et al. (2010) generated a series of selective type II inhibitors of PDGFR- $\beta$ and B-RAF targets for pericyte recruitment and endothelial survival, respectively and they demonstrated that dual inhibition of both PDGFR- $\beta$ and B-RAF exerted synergistic antiangiogenic activity in both zebrafish and murine models of angiogenesis.

Several other important studies with the aim to target pericytes have been conducted in experimental tumor models (Pietras and Hanahan, 2005; Maciag et al., 2008; Lu et al., 2010), and even in a human trial in advanced renal cell carcinoma (Haisnworth et al., 2007).

We have recently demonstrated that combined targeting of pericytes and endothelial tumor cells with a combination of a peptide ligand of aminopeptidase A (APA), disovered by phage display technology for deliver of liposomal doxorubicin (DXR) to perivascular tumor cells, and aminopeptidase N (APN)-targeted liposomal DXR enhances anti-tumor efficacy of liposomal chemotherapy in human neuroblastoma-bearing mice (Loi et al., 2010).

\section{Concluding remarks}

Pericytes are critical cells in vascular biology. They intervene at different levels of blood vessel formation, being involved in endothelial cell stimulation and guidance as well as endothelial stabilization and maturation. Signaling pathways operating in endothelial cell-pericyte cross-talk are currently being investigated and will provide crucial information on the paracrine molecular mechanisms controlling capillary formation (Fig. 3). This point is of critical interest in the physiopathological and clinical approach to degenerative vasculopathies as well as tumor angiogenesis. Finding drugs that allow manipulation of pericyte/endothelial cell interactions will provide physicians with a potent tool capable of controlling and blocking vascular proliferation and permeability. Increase of pericyte recruitment to stabilize new vessels will potentially ameliorate vascular disorders, such as diabetic retinopathy. In addition, a stable capillary microvasculature may represent an important prerequisite for preventing tumor cell dissemination. The future use of molecules interfering with the endothelial cell/pericyte unit will be also of interest in tissue engineering as well as the development of multi-tissue organs. Further studies are needed to highlight further aspects of pericyte molecular biology and physiology.

\section{Acknowledgements}

Supported in part by MIUR (PRIN 2007), Rome, AIRC, Milan, and Fondazione Cassa di Risparmio di Puglia, Bari, Italy.

\section{References}

ABRAMSSON, A., LINDBLOM, P. and BETSHOLTZ, C. (2003). Endothelial and nonendothelial sources of PDGF-B regulate pericyte recruitment and influence vascular pattern formation in tumors. J Clin Invest 112: 1142-1151.

ADAMS, R.H., WILKINSON, G.A., WEISS, C., DIELLA, F., GALE, N.W., DEUTSCH, U., RISAU, W. and KLEIN, R. (1999). Roles of ephrinB ligands and EphB receptors in cardiovascular development: demarcation of arterial/venous domains, vascular morphogenesis, and sprouting angiogenesis. Genes Dev 13: 295-306.

ALVA, J.A. and IRUELA-ARISPE, M.L. (2004). Notch signaling in vascular morphogenesis. Curr Opin Hematol 4: 278-283.

AMSELGRUBER, W.M., SCHAFER, M. and SINOWATZ, F. (1999). Angiogenesis in the bovine corpus luteum: an immunohistochemical and ultrastructural study. Anat Histol Embryol 28: 157-166.

BALUK, P., HASHIZUME, H. and MC DONALD, D.M. (2005). Cellular abnormalities of blood vessels as targets in cancer. Curr Opin Genet Dev 15: 102-111.

BARON, M., ASLAVM, H., FLASZA M., FOSTIER, M., HIGGS, J.E., MAZALEYRAT, S.L. and WILKIN, M.B. (2002). Multiple levels of Notch signal regulation (review). Mol Membr Biol 19: 27-38.

BENJAMIN, L.E., HEMO, I. and KESHET, E. (1998). A plasticity window for blood vessel remodeling is defined by pericyte coverage of the preformed endothelial network and is regulated by PDGF-B and VEGF. Development 125: 1591-1598.

BERGERS, G., SONG, S., MAYER-MORSE, N., BERGSLAND, E. and HANAHAN, D. (2003). Benefits of targeting both pericytes and endothelial cells in the tumor vasculature with kinase inhibitors. J Clin Invest 111: 1287-1295.

BERGERS, G. and SONG, S. (2005). The role of pericytes in blood-vessel formation and maintenance. Neuro Oncol 7: 452-464.

BETSHOLTZ, C. (2004). Insight into the physiological functions of PDGF through genetic studies in mice. Cytokine Growth Factor Rev 15: 215-228.

BLOOD, C.H. and ZETTER, B.R. (1990). Tumor interactions with the vasculature: 
angiogenesis and tumor metastasis. Biochem Biophys Acta 1032: 89-118.

BRATLEY-SIEDERS, D.M. and CHEN, J. (2004). Eph receptor tyrosine kinases in angiogenesis: from development to disease. Angiogenesis 7: 17-28.

CAI, J., KEHOE, O., SMITH, G.M., HYKIN, P. and BOULTON, M.E. (2008). The angiopoietin/Tie-2 system regulates pericyte survival and recruitment in diabetic retinopathy. Invest Ophthalmol Vis Sci 49: 2163-2171.

CAO, Y., SONVEAUX, P., LIU, S., ZHAO, Y., MI, J., CLARY, B.M., LI, C.Y., KONTOS, C.D. and DEWHIRST, M.W. (2007). Systemic overexpression of angiopoietin-2 promotes tumor microvessel regression and inhibits angiogenesis and tumor growth. Cancer Res 67: 3835-3844.

CLAXTON, S. and FRUTTIGER, M. (2004). Periodic Delta-like 4 expression in developing retinal arteries. Gene Expr Patterns 5: 123-127.

DARLAND, D.C. and D'AMORE, P.A. (2001). Cell-cell interactions in vascular development. Curr Top Dev Biol 52: 107-149.

DARLAND, D.C., MASSINGHAM, L.J., SMITH, S.R., SAINT-GENIEZ, M.'and D'AMORE, P.A. (2003). Pericyte production of cell-associated VEGF is differentiation-dependent and is associated with endothelial survival. Dev Biol 264: 275-288.

DE PALMA, M., VENNERI, M.A., GALLI, R., SERGI, L., POLITI, L.S., SAMPAOLESI, M. and NALDINI, L. (2005). Tie 2 identifies a hematopoietic lineage of proangiogenic monocytes required for tumor vessel formation and a mesenchymal population of pericyte progenitors. Cancer Cell 8: 211-226.

DIAZ-FLORES, L., GUTIÉRREZ, R. and VARELA, H. (1992). Behavior and lineage of postcapillary venule pericytes during postnatal angiogenesis. J Morphol213: 33-45.

FENG, Y., VOM HAGEN F., PFISTER, F., DjOKIC, S., HOFFMANN, S., BACK,W., WAGNER, P., LIN, J., DEUTSCH, U. and HAMMES, H.P. (2007). Impaired pericyte recruitment and abnormal retinal angiogenesis as a result of angiopoietin2 overexpression. Thromb Haemost 97: 99-108.

FOO, S.S., TURNER, C.J., ADAMS, S., COMPAGNI, A., AUBYN, D., KOGATA, N., LINDBLOM, P., SHANI, M., ZICHA, D. and ADAMS, R.H. (2006). Ephrin-B2 controls cell motility and adhesion during blood-vessel wall assembly. Cell 124: 161-173.

FUKUSHI, J., MAKAGIANSAR, I.T. and STALLCUP, W.B. (2004). NG2 proteoglycan promotes endothelial cell motility and angiogenesis via engagement of galectin3 and alpha 3 beta 1 integrin. Mol Biol Cell 15: 3580-3590.

GERETY, S.S., WANG, H.U., CHEN, Z.F. and ANDERSON, D.J. (1999). Symmetrical mutant phenotypes of the receptor EphB4 and its specific transmembrane ligand ephrin-B2 in cardiovascular development. Mol Cell 4: 403-414.

GERETY, S.S. and ANDERSON, D.J. (2002). Cardiovascular ephrinB2 is essential for embryonic angiogenesis. Development 129: 1397-1410.

GERHARDT, H. and BETSHOLTZ, C. (2003). Endothelial-pericyte interactions in angiogenesis. Cell Tissue Res 314: 15-23.

GERHARDT, H. and SEMB, H. (2008). Pericytes: gatekeepers in tumor cell metastasis? J Mol Med 86: 135-144.

GREENBERG, J.I., SHIELDS, D.J., BARILLAS, S.G., ACEVEDO, L.M., MURPHY, E.,HUANG, J., SCHEPPKE, L., STOCKMANN, C., JOHNSON, R.S., ANGLE, N. and CHERESH, D.A. (2008). A role for VEGF as a negative regulator of pericyte function and vessel maturation. Nature 456: 809-813.

HAINSWORTH, J.D., SPIGEL, D.R., SOSMAN, J.A., BURRIS, H.A. $3^{\text {rd }}$, FARLEY, C., CUCULLU, H., YOST, K., HART, L.L., SYLVESTER, L., WATERHOUSE, D.M. and GRECO, F.A. (2007). Treatment of advanced renal cell carcinoma with the combination bevacizumab/erlotinib/imatinib: a phase I/II trial. Clin Genitourin Cancer 5: 427-432.

HASHIZUME, H., BALUK, P., MORIKAWA, S., MC LEAN, J.W., THURSTON, G., ROBERGE, S., JAIN, R.K. and MC DONALD, D.M. (2000). Openings between defective endothelial cells explain tumor vessel leakiness. Am J Pathol 156: 1363-1380

HELLSTROM, M., KALEN, M., LINDAHL, P., ABRAMSSON, A. and BETSHOLTZ, C. (1999) Role of PDGF-B and PDGFR-beta in recruitment of vascular smooth muscle cells and pericytes during embryonic blood vessel formation in the mouse. Development 126: 3047-3055.

HOBBS, S.K., MONSKY, W.L., YUAN, F., ROBERTS, W.G., GRIFFITH, L., TORCHILIN, V.P. and JAIN, R.K. (1998). Regulation of transport pathways in tumor vessels: role of tumor type and microenvironment. Proc Natl Acad Sci USA 95: 4607-4612

HUGHES, C.C. (2008). Endothelial-stromal interactions in angiogenesis. Curr Opin Hematol 15: 204-209.

INAI, T., MANCUSO, M., HASHIZUME, H., BAFFERT, F., HASKELL, A., BALUK P., HU-LOWE, D.D., SHALINSKY, D.R., THURSTON, G., YANCOPOULOS, G.D. and MCDONALD, D.M. (2004). Inhibition of vascular endothelial growth factor (VEGF) signaling in cancer causes loss of endothelial fenestrations, regression of tumor vessels, and appearance of basement membrane ghosts. Am J Pathol 165: 35-52.

ISO T., HAMAMORI, Y. and KEDES, L. (2003). Notch signaling in vascular development. Arterioscler Thromb Vasc Biol 23: 543-553.

JAIN, R.K. 2005. Normalization of tumor vasculature: an emerging concept in antiangiogenic therapy. Science 307: 58-62.

JONES, N., ILJIN, K., DUMONT, D.J. and ALITALO, K. (2001). Tie receptors: new modulators of angiogenic and lymphangiogenic responses. Nat Rev Mol Cell Biol 2: 257-267.

KASHIWAGI, S., IZUMI, Y., GOHONGI, T., DEMOU, Z.N., XU, L., HUANG, P.L., BUERK, D.G., MUNN, L.L., JAIN, R.K. and FUKUMURA, D. (2005). NO mediates mural cell recruitment and vessel morphogenesis in murine melanomas and tissue-engineered blood vessels. J Clin Invest 115: 181618-181627.

KUWABARA, T. and COGAN, D.G. (1963). Retinal vascular patterns. VI. Mural cells of the retinal capillaries. Arch Ophthalmol 69: 492-502.

LEBRIN, F., DECKERS, M., BERTOLINO, P. and TEN DIJKE, P. (2005). TGF-beta receptor function in the endothelium. Cardiovasc Res, 65: 599-608.

LEVEEN, P., PEKNY, M., GEBRE-MEDHIN, S., SWOLIN, B., LARSSON, E. and BETSHOLTZ, C. (1994). Mice deficient for PDGFB show renal, cardiovascular and hematological abnormalities. Genes Dev, 8: 1975-1987.

LI, D.Y., SORENSEN, L.K., BROOKE, B.S., URNESS, L.D., DAVIS, E.C., TAYLOR, D.G., BOAK, B.B. and WENDEL, D.P. (1999). Defective angiogenesis in mice lacking endoglin. Science 284: 1534-1537.

LINDBLOM, P., GERHARDT, H., LIEBNER, S., ABRAMSSON, A., ENGE, M., HELLSTROM, M., BACKSTROM, G., FREDRIKSSON, S., LANDEGREN, U., NYSTROM, H.C., BERGSTROM, G., DEJANA, E., OSTMAN, A., LINDAHL, P. and BETSHOLTZ, C., (2003). Endothelial PDGF-B retention is required for proper investment of pericyte in the microvessel wall. Genes Dev 17: 19351840.

LIU, H., KENNARD, S. and LILLY, B. (2009). NOTCH3 expression is induced in mural cells through an autoregulatory loop that requires endothelial-expressed JAGGED1. Cir Res 104: 466-475.

LOI, M., MARCHIO', S., BECHERINI, P., DI PAOLO, D., SOSTER, M., CURNIS, F., BRIGNOLE, C., PAGNAN, G., PERRI, P., CAFFA, I., LONGHI, R., NICO, B., BUSSOLINO, F., GAMBINI, C., RIBATTI, D., CILLI, N., ARAP, W., PASQUALINI, R., ALLEN, T.M., CORTI, A., PONZONI, M. and PASTORINO, F. (2010). Combined targeting of perivascular and endothelial tumor cells enhances antitumor efficacy of liposomal chemotherapy in neuroblastoma. J Control Release 145: $66-73$.

LOUVI, A., ARBOLEDA-VELASQUEZ, J.F. and ARTAVANIS-TSAKONAS, S. (2006). CADASIL: a critical look at a Notch disease. Dev Neurosci 28: 5-12.

LOVSCHALL, H., MITSIADIST, A., POULSEN; K., JENSEN, K.H. and KJELDSEN, A.L. (2007). Coexpression of Notch3 and Rgs5 in the pericyte-vascular smooth muscle cell axis in response to pulp injury. Int $J$ Dev Biol 51: 715-721.

LU, C., SHAHZAD, M.M., MORENO-SMITH, M., LIN, Y.G., JENNINGS, N.B., ALLEN, J.K., LANDEN, C.N., MANGALA, L.S., ARMAIZ-PENA, G.N., SCHMANDT, R., NICK, A.M., STONE, R.L., JAGGE, R.B., COLEMAN, R.L. and SOOD, A.K. (2010). Targeting pericytes with a PDGF-B aptamer in human ovarian carcinoma models. Cancer Biol Ther 9: 176-182.

MACIAG, P.C., SEAVEY, M.M., PAN, Z.K., FERRONE, S. and PATERSON, Y. (2008). Cancer immunotherapy targeting the high molecular weight melanomaassociated antigen protein results in a broad antitumor response and reduction of pericytes in the tumor vasculature. Cancer Res 68: 8066-8075.

MAISONPIERRE, P.C., SURI, C., JONES, P.F., BARTUNKOVA, S., WIEGAND, S.J., RADZIEJWSKI, C., COMPTON, D., MCCLAIN, J., ALDRICH, T.H., PAPADOPOULOS, N., DALY, T.J., DAVIS, S., SATO, T.N. and YANCOPOULOS G.D. (1997). Angiopoietin-2, a natural antagonist for Tie 2 that disrupts in vivo 
angiogenesis. Science 277: 55-60.

MANCUSO, M.R., DAVIS, R., NORBERG, S.M., O'BRIEN, S., SENNINO, B., NAKAHARA, T., YAO, V.J., INAI, T., BROOKS, P., FREIMARK, B., SHALINSKY, D.R., HU-LOWE, D.D. and MCDONALD, D.M. (2006). Rapid vascular regrowth in tumors after reversal of VEGF inhibition. J Clin Invest 116: 2610-2621.

MAYER, S. (1902). Die Muscularisierung der kapillaren Blutgefässe. Anat Anz 21: $442-455$.

MORIKAWA, S., BALUK, P., KAIDOH, T., HASKELL, A., JAIN, R.K. and MCDONALD, D.M., (2002). Abnormalities in pericytes on blood vessels and endothelial sprouts in tumors. Am J Pathol 160: 985-1000.

MURPHY, E.A., SHIELDS, D.J., STOLETOV, K., DNEPROVSKAIA, E., MCELROY, M., GREENBERG, J.I., LINDQUIST, J., ACEVEDO, L.M., ANAND, S., MAJETI, B.K., TSIGELNY, I., SALDANHA, A., WALSH, B., HOFFMAN, R.M., BOUVET, M., KLEMKE, R.L., VOGT, P.K., ARNOLD, L., WRASIDLO, W. and CHERESH, D.A. (2010). Disruption of angiogenesis and tumor growth with an orally active drug that stabilzes the inactive state of PDGFR//B-RAF. Proc Natl Acad Sci USA 107: 4299-4304.

NEHLS, V., DENZER, K., DRENCKHAHN, D. (1992). Pericyte involvement in capillary sprouting during angiogenesis in situ. Cell Tissue Res 270: 469-474.

NEHLS, V. and DRENCKHAHN, D. (1993). The versatily of microvascular pericytes: from mesenchyme to smooth muscle? Histochemistry 99: 1-12.

OHLSSON, R., FALCK, P., HELLSTROM, M., LINDAHL, P., BOSTROM, H. FRANKLIN, G., AHRLUND-RICHTER, L., POLLARD, J., SORIANO, P. and BESTSHOLTZ, C. (1999). PDGFB regulates the development of the labyrinthine layer of the mouse fetal placenta. Dev Biol 212: 124-136.

ORLIDGE, A. and D'AMORE, P.A. (1987). Inhibition of capillary endothelial cell growth by pericytes and smooth muscle cells. J Cell Biol 105: 1455-1462.

OZERDEM, U. and STALLCUP, W.B. (2003). Early contribution of pericytes to angiogenic sprouting and tube formation. Angiogenesis 6: 241-249.

OZERDEM, U. and STALLCUP, W.B. (2004). Pathological angiogenesis is reduced by targeting pericytes via the NG2 proteoglycan. Angiogenesis 7: 269-276.

PATAN, S. (1998). TIE1 and TIE2 receptor tyrosine kinases inversely regulate embryonic angiogenesis by the mechanism of intussusceptive microvascular growth. Microvasc Res 56: 1-21.

PETRAS, K. and HANAHAN, D. (2005). A multitargeted, metronomic, and maximum-tolerated dose "chemo-switch" regimen is antiangiogenic, producing objective responses and survival benefit in a mouse model of cancer. J Clin Oncol 23: 939-952.

RAJANTIE, I., ILMONEN, M., ALMINAITE, A., OZERDEM, U., ALITALO, K. and SALVEN, P. (2004). Adult bone marrow-derived cells recruited during angiogenesis comprise precursors for periendothelial vascular mural cells. Blood, 104: 2084-2086.

REINMUTH, N., LIU, W., JUNG, Y.D., AHMAD, S.A., SHAHEEN, R.M., FAN, F., BUCANA, C.D., MCMAHON, G., GALLICK, G.E. and ELLIS, L.M. (2001). Induction of VEGF in perivascular cells defines a potential paracrine mechanism for endothelial cell survival. FASEB J 15: 1239-1241.

ROUGET, C. (1873). Mémoire sur le développment, la structure et les propertiés physiologiques des capillaries sanguins et lymphatiques. Arch Physiol Norm Pathol 5: 603-663.

ROUGET, C. (1874). Note sur le dévelopment de la tunique contractile des vaissaux. Compt Rend Acad Sci Paros 59: 559-562.

ROUGET, C. (1879). Sur la contractilité des capillaires sanguins. Compt Rend Acad Sci Paris 88: 916-918.

SALVUCCI, O., MARIC, D., ECONOMOPOLOU M., SAKAKIBARA, S., MERLIN, S., FOLLENZI, A. and TOSATO, G. (2009). Ephrin B reverse signaling contributes to endothelial and mural cell assembly into vascular structures. Blood 114: 1707-1716.

SATO, Y. and RIFKIN, D.B. (1989). Inhibition of endothelial cell movement by pericytes and smooth muscle cells: activation of a latent transforming growth factor-beta 1-like molecule by plasmin during co-culture. J Cell Biol 109: 309315.

SCHLINGEMANN, R.O., RIETVELD, F.J., DE WALL, R.M., FERRONE, S. and RUITE, D.J. (1990). Expression of the high molecular weight melanomaassociated antigen by pericytes during angiogenesis in tumors and in healing wounds. Am J Pathol 136: 1393-1405

SENNINO, B., FALCON, B.L., MCCAULEY, D., LE, T., MCCAULEY, T., KURZ, J.C., HASKELL, A., EPSTEIN, D.M. and MCDONALD, D.M. (2007). Sequential loss of tumor vessel pericytes and endothelial cells after inhibition of plateletderived growth factor B by selective aptamer AX102. Cancer Res 67: 73587367.

SHAHEEN, R.M., TSENG, W.W., DAVIS, D.W., LIU, W., REINMUTH, N., VELLAGAS, R., WIECZOREK, A.A., OGURA, Y., MCCONKEY, D.J., DRAZAN K.E., BUCANA, C.D., MCMAHON, G. and ELLIS, L.M. (2001). Tyrosine kinase inhibition of multiple angiogenic growth factor receptors improves survival in mice bearing colon cancer liver metastases by inhibition of endothelial cell survival mechanism. Cancer Res 61: 1464-1468.

SONG, S., EWALD, A.J., STALLCUP, W., WERB, Z. and BERGERS, G., (2005) $P D G F R \beta^{+}$perivascular progenitor cells in tumours regulate pericyte differentiation and vascular survival. Nat Cell Biol 7: 870-879.

STRATMAN, A.N., MALOTTE, K.M., MAHAN, R.D., DAVIS, M.J. and DAVIS, G.E (2009). Pericyte recruitment during vasculogenic tube assembly stimulates endothelial basement membrane matrix formation. Blood 114: 5091-5101.

SUNDBERG, C., KOWANETZ, M., BROWN, L.F., DETMAR, M. AND DVORAK, H.F. (2002). Stable expression of angiopoietin-1 and other markers by cultured pericytes: phenotypic similarities to a subpopulation of cells in maturing vessels during later stages of angiogenesis in vivo. Lab Invest 82: 387-401.

THURSTON, G., SURI, C., SMITH, K., MC CLAIN, J., SATO, T.N., YANCOPOULOS, G.D. and MC DONALD, D.M. (1999). Leakage-resistant blood vessels in mice transgenically overexpressing angiopoietin-1. Science 286: 2511-2514.

THURSTON, G. (2003). Role of angiopoietins and Tie receptor tyrosine kinases in angiogenesis and lymphangiogenesis. Cell Tissue Res 314: 61-68.

TONG, R.T., BOUCHER, Y., KOZIN, S.V., WINKLER, F., HICKLIN, D.J. and JAIN, R.K., (2004). Vascular normalization by vascular endothelial growth factor receptor 2 blockade induces a pressure gradient across the vasculature and improves drug penetration in tumors. Cancer Res 64: 3731-3736.

UEMURA, A., OGAWA, M., HIRASHIMA, M., FUJIWARA, T., KOYAMA, S., TAKAGI, H., HONDA, Y., WIEGAND, S.J., YANCOPOULOS, G.D. and NISHIKAWA, S. (2002). Recombinant angiopoietin-1 restores higher-order architecture of growing blood vessels in mice in the absence of mural cells. J Clin Invest 110: 1615-1817.

VIMTRUP, B.J. (1922). Beitrage zur Anatomie der kapillaren. Ubër contractile Elemente in der Gefäßwand der Blutcapillaren. Zeitschr Anat Entwickl 45: 392 399.

VIRGINTINO, D., GIROLAMO, F., ERREDE, M., CAPOBIANCO, C., ROBERTSON, D., STALLCUP, W.D., PERRIS, R. and RONCALI, L. (2007). An intimate interplay between precocius, migrating pericytes and endothelial cells govern human fetal brain angiogenesis. Angiogenesis 10: 35-45.

VON TELL, D., ARMULIK, A. and BETSHOLTZ. C. (2006). Pericytes and vascular stability. Exp Cell Res 312: 623-629.

WAKUI, S., YOKOO, K., MUTO, T., SUZUKI, Y., TAKAHASHI, M., FURUSATO, M. HANO, H., ENDOU, H. and KANAI, Y. (2006). Localization of Ang-1, -2, Tie-2, and VEGF expression at endothelial-pericyte interdigitation in rat angiogenesis. Lab Invest 86: 1172-1184.

WANG, H., CHEN, Z. and ANDERSON, D. (1998). Molecular distinction and angiogenic interaction between embryonic arteries and veins revealed by ephrin-B2 and its receptor Eph-B4. Cell 93: 741-753.

WANG, T., BARON, M. and TRUMP, D. (2007). An overview of Notch 3 function in vascular smooth muscle cells. Prog Biophys Mol Biol 96: 499-509.

WESSELING, P., SCHLINGEMANN, R.O., RIETVELD, F.J., LINK, M., BURGER, P.C. and RUITER, D.J. (1995) Early and extensive contribution of pericytes/ vascular smooth muscle cells to microvascular proliferation in glioblastoma multiforme: an immuno-light and immuno-electron microscopic study. $J$ Neuropathol Exp Neurol 54: 304-310.

WILLETT, C.G., BOUCHER, Y., DI TOMASO, E., DUDA, D.G., MUNN, L.L., TONG, R.T., CHUNG, D.C., SAHANI, D.V., KALVA, S.P., KOZIN, S.V., MINO, M., COHEN, K.S., SCADDEN, D.T., HARTFORD, A.C., FISCHMAN, A.J., CLARK, J.W., RYAN, D.P., ZHU, A.X., BLASZKOWSKY, L.S., CHEN, H.X., SHELLITO, P.C., LAUWERS, G.Y. and JAIN, R.K. (2004). Direct evidence that the VEGFspecific antibody bevacizumab has antivascular effects in human rectal cancer. Nat Med 10: 145-147. 
YAMAGISHI, S., YONEKURA, H., YAMAMOTO, Y., FUJIMORI, H., SAKURAI, S., TANAKA, N. and YAMAMOTO, H. (1999). Vascular endothelial growth factor acts as a pericyte mitogen under hypoxic conditions. Lab Invest 79: 501-509.

ZHANG, L., YANG, N., PARK, J.W., KATSAROS, D., FRACCHIOLI, S., CAO, G., O'BRIEN-JENKINS, A., RANDALL, T.C., RUBIN, S.C., COUKOS, G. (2003).
Tumor-derived vascular endothelial growth factor up-regulates angiopoietin-2 in host endothelium and destabilizes host vasculature, supporting angiogenesis in ovarian cancer. Cancer Res 63: 3403-3412.

ZIMMERMANN, K.W. (1923). Der feinere Bau der Blutkapillaren. Z Anat Entwick 68: 29-36.

\section{Further Related Reading, published previously in the Int. J. Dev. Biol.}

The contribution of Roberto Montesano to the study of Interactions between epithelial sheets and the surrounding extracellular matrix

Domenico Ribatti

Int. J. Dev. Biol. (2010) 54: 1-6

The seminal work of Werner Risau in the study of the development of the vascular system Domenico Ribatti

Int. J. Dev. Biol. (2010) 54: 567-572

Coexpression of Notch3 and Rgs5 in the pericyte-vascular smooth muscle cell axis in response to pulp injury Henrik Lovschall, Thimios A. Mitsiadis, Knud Poulsen, Kristina H. Jensen and Annette L. Kjeldsen Int. J. Dev. Biol. (2007) 51: 715-721

An activating mutation in the PDGF receptor-beta causes abnormal morphology in the mouse placenta Camilla Looman, Tong Sun, Yang Yu, Agata Zieba, Aive Ahgren, Ricardo Feinstein, Henrik Forsberg, Carina Hellberg, Carl-Henrik Heldin, Xiao-Qun Zhang, Karin Forsberg-Nilsson, Nelson Khoo, Reinald Fundele and Rainer Heuchel

Int. J. Dev. Biol. (2007) 51: 361-370

Vasculogenesis and angiogenesis in the mouse embryo studied using quail/mouse chimeras Michel Pudliszewski and Luc Pardanaud

Int. J. Dev. Biol. (2005) 49: 355-361

5 yr ISI Impact Factor $(2009)=3.253$

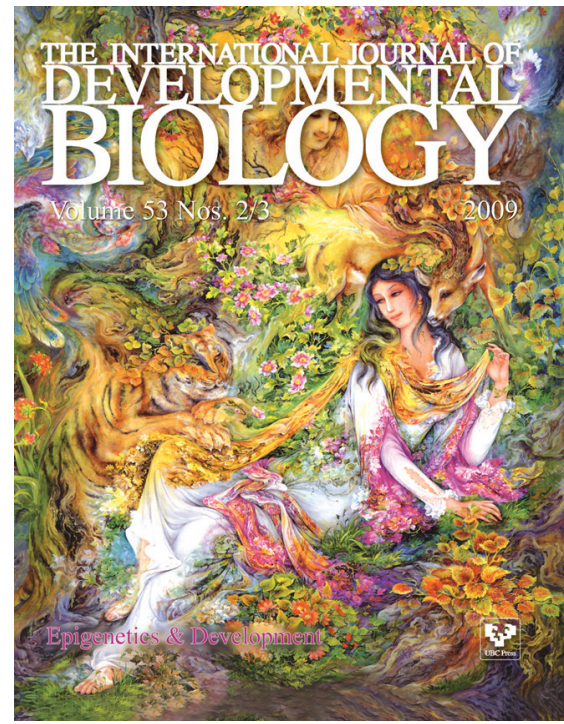

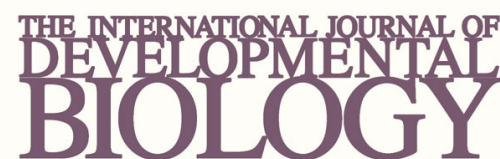

Volume 54 Nos. 6/7

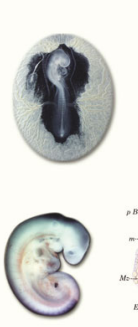

Special Issue

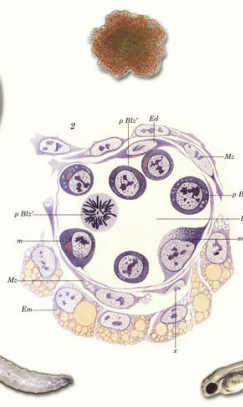

Developmental Hematopoiesis

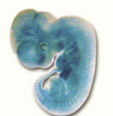

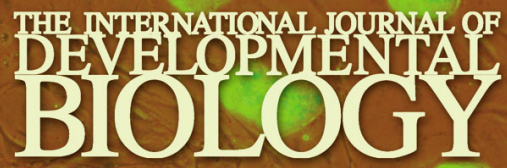

Volume 54 Nos $11 / 12$

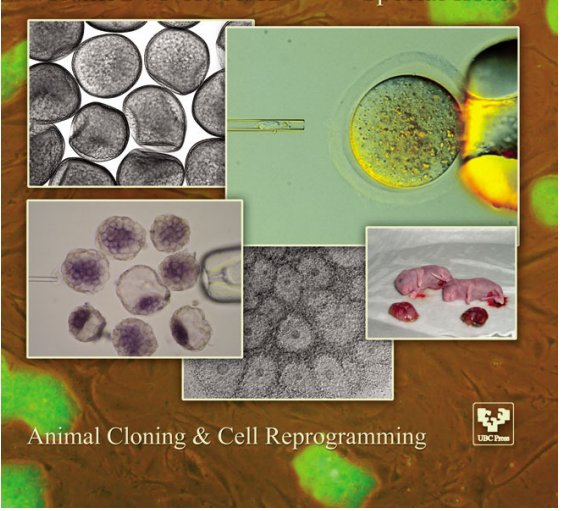

